\title{
Teologisering vir die gesekulariseerde mens
}

\author{
JH Koekemoer \\ Universiteit van Pretoria
}

\begin{abstract}
Doing theology for secularised man
\end{abstract}

One of the problems of theology today is how to tell the story of Jesus to modern man in such a way that he still can belief in God. Paul van Buren tried to make the gospel comprehensible to modern man by making use of the verification principle of linguistic analysis, and he consequently reduced the whole of the gospel to a single content, that of freedom, around which he them thematised a theology that according to him, should be relevant. By bringing about this reduction he argued that the gospel should be stripped of all metaphysical content so that it could pass the test of verification and lay claim to truth and reality. Because he argued in terms of the logic postivism we can not accept his method. But the issue is still on the table namely: How to translate the gospel and the simbols of the church in such a way that it still can communicate with modern man. On this issue the Dogmatics is still working and by using various methods tries to find answers on this important issue.

\section{1. 'N POGING TOT TEOLOGISERING TEN BEHOEWE VAN DIE GESEKULARISEERDE MENS}

\subsection{Probleemstelling}

Dat die kerk voor enorme vrae staan by die bring van die evangelie aan die 'gesekulariseerde' mens van vandag is nie te betwyfel nie. Die vraag is uiteindelik hoe die kerk die vrae gaan beantwoord sodat die evangelie aan die wêreld verkondig kan word en sodat die mense steeds kan glo dat Jesus die Here is. 
Die antwoord kan natuurlik gegee word dat daar niks nuuts te sê is nie, en dat die kerk maar net kan nasê wat reeds vantevore gesê is. Die vraag wat so 'n antwoord sou oproep is of teologisering dan nog enige sin het. As ons so geariveerd geraak het, hoekom dan nog teologies bedrywig wees?

Aan die anderkant kan ernstige pogings aangewend word om die evangelie so aan die gesekulariseerde mens te verkondig dat hy dit kan glo. In die verband is teoloë steeds besig om te worstel om die waarheid so hoorbaar te maak dat dit die mens van ons dag nog aanspreek en oproep tot geloof.

\section{2 'n Voorstel tot 'n oplossing (Van Buren 1966, 1967 en 1968)}

Paul van Buren het dit eenmaal as sy oortuiging gestel dat daar groot waardering vir die wyse waarop die vadere geteologiseer het, moet wees. Daar behoort ook wel deeglik van hulle pogings kennis geneem te word. In die verband moet ons egter steeds in gedagte hou dat hulle denkpatroon en spreekwyse vir gesekulariseerde mense vreemd is en nie sonder meer aanvaar kan word nie. 'n Teologiese denkpatroon eie aan die 20ste eeu en 'n spreekwyse verstaanbaar vir die mens van vandag, blyk uiters noodsaaklik te wees.

Natuurlik het die evangelie met Jesus van Nasaret te doen. So sien die skrywer van Handelinge immers ook die evangelie aangaande Jesus van Nasaret: 'God het Jesus van Nasaret aan julle bekend gestel deur kragtige dade, die wonders en tekens wat God Hom by julle laat doen het' (Hand 2:22), of soos Paulus dit stel: Die evangelie van God is 'n evangelie aangaande Jesus. 'As 'n mens is Hy uit die geslag van Dawid gebore' (Rom 1: 3 ). In 'n nuwe besinning oor die evangelie is dit dan belangrik dat ons sal onthou dat wanneer ons oor die taal van die Christelike geloof handel, dat die taal dan altyd te doen het met 'n spesifieke mens wat in Palestina geleef en gewerk het.

In so 'n teologisering kan dit nie gaan om die 'skilder' van 'n portret van Jesus nie, omdat die negentiende-eeuse poging in hierdie verband reeds ' $n$ mislukking was. Volgens Bultmann het dit nie geslaag nie, omdat die materiaal tot ons beskikking nie 'n volledige biografie van Jesus gee nie. Die historici kan alleen maar enkele dinge van Hom te wete kom. Die meeste wat ons van Jesus weet, is wat ons deur middel van die prediking van die vroeë Christelike kerk te wete kom. Maar nou het dit vir die prediking nie om historiese feite gegaan nie, maar om ' $n$ 'verhaal' in diens van die Paas-kerugma. En omdat Bultmann se belangstelling in die kerugma geleë is, is hy derhalwe ook nie uitermate bekommerd oor die historiese gebeurtenisse nie (Bultmann 1951). 
Om ten opsigte van die saak tot sy eie standpunt te kom, gee Van Buren ook ander standpunte weer. Dit sal goed wees om kortliks hierna te kyk, aangesien dit ook daartoe sal bydra om uiteindelik 'n beter begrip van sy eie standpunt te verkry. Hy sê dat Barth die getuienis aangaande Jesus sien as 'n stuk van die geskiedenis van God se selfopenbaring in Jesus. Wat belangrik is, is dat God gehandel het, Jesus Christus uit die dode opgewek het en die apostels uitgestuur het as getuies hiervan. Niks meer moet agter die geskiedenis gesoek word nie. Daarom moet daar ook nie 'n geskiedenis agter die teks gesoek word nie. Want dit is die geskiedenis, nie van 'n mens nie, nie van 'n religieuse leier nie, maar van Gods genadige handeling in en vir die wêreld. Dit is wat belangrik is en hiervan gee die Nuwe Testament die nodige getuienis. Verdere biografiese en psigologiese informasie aangaande Jesus sal nie help om hierdie gebeure beter te verstaan nie.

'n Groep leerlinge van Bultmann onder leiding van Käsemann het weer begin met $A$ new quest of the historical Jesus. Hulle was nie van plan om die pogings om 'n lewe van Jesus te rekonstrueer, te laat herleef nie. Daar word alleen gestel dat die feit dat die kerugma met Jesus van Nasaret te doen het en die feit dat die mondelinge tradisie wat vir die eerste dissipels so belangrik was, baie te sê het oor die geskiedenis van Jesus voor Paasfees, dit ons uitdaag om verdere historiese navorsing te doen. Vir hulle is dit ongetwyfeld waar dat die berigte aangaande Jesus gekleur is en dikwels getemper is deur die Paas-gebeure. Nou is ons taak nie om 'n biografie van Jesus te probeer skryf nie, want dit is onmoontlik, maar om verskillende perspektiewe van die mens, Jesus van Nasaret, te verkry. Van Buren wil voortbou op laasgenoemde wyse van spreke oor die geskiedenis en hy wil met die oog op ' $n$ teologiese besinning vir die gesekulariseerde mens met behulp van die 'linquistic analysis' sekere karakteristieke van Jesus bespreek soos dit na vore gebring is.

Wie teologies so dink kom agter dat Jesus van Nasaret 'n individu was wie se karakter Sy volgelinge klaarblyklik so beïndruk het dat Hy uitgetroon het as 'n merkwaardige vry mens. Daarom kan ons die mens en optrede van Jesus dan ook beskryf met sekere begrippe byvoorbeeld vryheid en geloof.

Van Buren verkies vryheid omdat geloof 'n mens kan lei op die gevaarlik gladde weg van die nie-empiriese. Die evangeliste gebruik die term vryheid in verband met Jesus op verskillende maniere. So kan dit byvoorbeeld op sy gesag dui of op sy openheid teenoor vriend en vyand. Alhoewel Jesus byvoorbeeld as 'n gehoorsame kind van sy ouers beskrywe word, word Hy ook geskets as vry van familie-aansprake (Luk 2: 51; Mark 3: 31-35). Hy het die religieuse gebruike en instellinge van Sy mense nagevolg, maar Hom ook vry gevoel om dit te negeer (Matt 17: 24-27, Mark 2: 23-27; Luk 17: 14). 
In die wonders word Hy selfs mitologies voorgestel as iemand wat $v r y$ was van die beperkinge van die natuur. Die inhoud van die prediking van Jesus vertoon vir hom hierdie selfde vryheid. Hy was vry van die gretigheid en noodsaaklikheid om sy eie identiteit te bevestig, maar boweal was Hy vry vir sy medemens.

Vir hom is dit derhalwe duidelik dat vir 'n geskulariseerde wêreld daar veel oor Jesus gesê kan word deur gebruikmaking van dit wat in Jesus na vore tree rondom die konsep vnyheid.

Daarom moet ons dit dan ook so verstaan dat wanneer die Nuwe Testament oor Jesus praat en sê dat $\mathrm{Hy}$ een van ons was, dan beteken dit dat Hy volkome mens was. Met die kwalifikasie 'maar sonder sonde' wil die Nuwe Testament sy vryheid na vore bring. Jesus as 'n histories empiriese figuur het die vryheid geleef - Hy was vry van die tradisie en die kerk, vry van die sorg vir die toekoms, vry vir die vryheid en vry vir Sy medemens. Dit is hierdie vryheid wat dan ook tot Sy kruisiging gelei het.

Dit is hierdie Jesus wat ons aanspoor en uitdaag om self vry te wees. Daarom moet ons die evangelie dan ook verstaan as 'n goeie tyding van ' $n$ vry mens wat ook ander vrygemaak het. Eers na Pase kan so 'n evangelie egter werklik sinvol verstaan en geïnterpreteer word.

In die beoefening van die teologie kan dit gebeur dat 'n teologiese tradisie so 'n houvas op Christene verkry dat hulle geneig is om die woorde van die Bybel te lees in die lig van hulle latere teologiese gebruike. Dit het veral gebeur ten opsigte van woorde soos 'God', 'Seun van God' en 'Christus'.

Volgens die Nuwe Testament was die woord 'Christus' eers aanduiding van 'n titel en later, waarskynlik nog voor die einde van die Nuwe-Testamentiese tydvak, is dit as eienaam gebruik.

Omdat dit aanvanklik aanduiding van 'n 'ampstitel' was, dui dit op iets meer as net ' $n$ ander vorm van die naam 'Jesus'. Dit sou beter wees om die duistere woord 'Christus' te vermy en dan na die sentrale figuur van die evangelies te verwys as 'Jesus' of 'Jesus van Nasaret'. Die amp 'Christus' kan aangedui word deur die Hebreeuse woord 'Messias' te gebruik.

'Christus' is die een wat aan ons 'n nuwe 'blik' (Van Buren 1966: 85) en 'n nuwe historiese perspektief gee. Daarom het die evangelie ook vir die dissipels die karakter van 'n 'blik' gehad. Dit beteken dat die evangelie 'n boodskap van vryheid is wat die geloof van die dissipels beskryf, die geloof wat 'n bewuswording daarvan is dat Jesus vir hulle en dan ook vir ons die weg van vryheid uitgestip het.

Jou eie lewenshouding van 'n vry mens vir andere te wees, sal dan hierdie geloof verifieer.

Om in Christus te glo en 'n Christen te wees, sal derhalwe beteken om deel te hê aan die vryheid van Jesus van Nasaret. Hierdie vryheid wat Jesus aan ons gee, $s$ 
die vryheid wat Hyself geleef het. Dit kan eintlik nie beskryf word nie, maar in Jesus en in die 'glimpses' van Hom wat ons in die evangelies vind, staan 'n beeld van die vryheid voor ons. Hy was vry van homself, vry van selfbehoud en selfhandhawing, vry vir ander mense.

Volgens Van Buren het die empiries-linguistiese analise aangetoon dat nie alleen die werklikheid nie, maar ook die woord 'God' in die wetenskaplike denke en spreke onbruikbaar geword het. Oor 'God' moet ons nie praat nie. Dit mag miskien beter wees om die woord יהרה 'te gebruik in plaas van die woord 'God'.

Op dieselfde wyse is die titel 'Seun van God' problematies en moet daaroor ook duidelikheid verkry word. Dit is wel waar dat die titel 'Seun van God', in die Nuwe Testament aan Jesus toegeskryf word, maar dit het 'n lang geskiedenis. Wie dit dus enigsins reg wil verstaan, sal in elk geval ook aan hierdie agtergrond aandag moet gee. Die titel 'Seun van God' is vir die eerste keer in die Ou Testament gebruik in verband met Israel en dan ook spesifiek in verband met diegene wat die verbondsvolk verteenwoordig het, byvoorbeeld die priester of die koning. Dit is dus duidelik dat die titel op dienende gehoorsaamheid dui.

Deur Jesus nou die 'Seun van God' te noem, wou die apostels sé dat die ware Israel nou gekom het. Hy was wat Israel nie kon wees nie, naamlik 'n lig tot verligting van die nasies. Jesus was die draer van 'n spesifieke roeping en opdrag en dit bied vir Van Buren 'n basis om 'n Christologie van 'call' en 'response' te ontwikkel. Hy wil sy stelling bewys deur te verwys na Johannes 9: 29-33 en 10: 3038.

In Johannes 10: 30-38 sê Jesus dat om 'in die Vader' te wees en om die Vader 'in' Hom te hê, dieselfde beteken as om 'Seun van God', genoem te word. Maar om 'Seun van God' te wees, beteken weer 'om die werke van die Vader te doen' en die een te wees na wie die Woord van God gekom het, verwysende na Psalm 82: 6.

Dit sou beteken om 'n opdrag van God te hê en om gehoorsaam te wees aan daardie opdrag. Dit is belangrik om hier te onthou dat dit nie gaan om die hemelse wyding en inkarnasie nie, maar om die aardse roeping en sending van Jesus.

Ons moet egter Johannes 14: 9, 'Wie my sien, sien die Vader', in hierdie verband ook in gedagte hou. Jesus gebruik hier die woord 'Vader' in plaas van die woord 'God'. Christene word dus gevra om op te hou soek na die Vader. Die Bybel wil hiermee aan ons baie duidelik sê dat die 'Vader' nie los van Jesus te vind is nie, en dat die Vader slegs in 'Jesus' is. Hiermee word die vraag na God deur die Nuwe Testament dan ook beantwoord deur na die mens Jesus te verwys. Wat die mens ook al gesoek het deur na 'God' te soek, is te vind in 'Jesus van Nasaret'. Teruggevoer na die konsep vryheid beteken dit die vryheid van Jesus en hoe 'n mens 
iets van hierdie vryheid kan verkry.

Wanneer daar ten behoewe van die gesekulariseerde mens geteologiseer moet word, moet ook aandag gegee word aan die belydenis 'Jesus is die Here' omdat dit die oudste en basiese vorm van 'n belydenis is (Cullmann 1943).

Die empiriese grond van die belydenis, sê Van Buren, is geleë in die geskiedenis van Jesus en in die dade van die gelowige. Die logika van die belydenis is daarin geleë dat dit praktiese konsekwensies vir die mens meebring wat bely 'Jesus is die Here'. Dit beteken dat die Christelike geloof 'n sekere manier van lewe word. Die mens wat bely 'Jesus is die Here', sê dat die geskiedenis van Jesus en wat op pase gebeur het, 'n bevrydende invloed op hom uitoefen en dat hy so daardeur in besit geneem is dat dit die historiese norm van sy lewensbeskouing geword het.

Hierdie stelling word met 'n voorbeeld geillustreer: 'n Mens se lewensbeskouing kan ook in ander dinge gegrond wees, byvoorbeeld in die lewe van jou volk. So 'n persoon sien homself dan eerstens as 'n patriot en definieer sy vryheid in verband met sy lojaliteit teenoor sy land. Vir hom kan die evangelie alleen relatiewe betekenis hê. Hy mag toegee dat daar'n sekere mate van vryheid in Jesus se lewe te vinde is, maar vir hom is dit ondergeskik aan sy vryheid as burger van sy land. Daarom kan 'n egte nasionalis nooit in die ware sin van die woord 'n Christen wees nie. Want vir 'n Christen wat bely 'Jesus is die Here' is Jesus die oriëntasiepunt. Vir hom hou hierdie belydenis in dat hy ook vry is van finale lojaliteit teenoor sy volk, sy familie, sy kerk, en so meer. Met die belydenis dat 'Jesus die Here is', sê die gelowige dat Jesus se vryheid aansteeklik is en die kriterium vir sy private en openbare lewe geword het. Dit sal impliseer dat, net soos Jesus deur sy vryheid in sosiale en politieke konflikte gelei is, so sal dit ook wees met die mens wat hierdie vryheid deel.

Ook die leer van die inkarnasie moet dringende aandag ontvang. Van Buren oordeel dat die leer van die twee nature van Christus nie in die Nuwe Testament teruggevind kan word nie. Dit is wel waar dat dit 'n interpretasie van die vadere was, maar wanneer ons aanvaar dat die evangelie ook vir gesekulariseerde en geïndustrialiseerde mense bedoel is, dan is ons verplig om ook hier 'n eie interpretasie te maak. By sy waardering vir die poging van die vadere is ook sy bekommernis dat die terme wat gebruik word metafisies gerig is en daarom vandag nie meer bruikbaar is nie. Inteendeel is hy van mening dat, alhoewel die vadere getrou wou wees aan die Bybelse inhoud, hulle die bedoeling van die Nuwe-Testamentiese skrywers nie reg weergegee het nie.

Van Buren het een groot probleem in verband met die ortodokse Christologie, naamlik dat dit, gesien in moderne perspektief, nie reg laat geskied aan die 
mensheid van Jesus nie. Die fout kan, volgens hom, alreeds by Justinus die Martelaar opgemerk word.

Hy het byvoorbeeld gestel dat Jesus volkome mens was na siel, liggaam en gees, maar dat Hy geen historiese verwantskap gehad het nie, as gevolg van Sy wonderbare geboorte. Die Nuwe Testament stel egter iets van Jesus wat Justinus klaarblyklik nie raakgesien het nie, naamlik sy verwantskap met ander mense.

Wanneer na die redes vir die verwerping van die leerstellinge van Apollinarus gekyk word, word dit volgens hom nog duideliker dat die vadere by implikasie alle pogings om Jesus van ander mense te onderskei op grond van Sy menselike natuur, verwerp het. Hulle het wel gestel dat Hy volkome mens was, maar hulle formule van twee nature verenig in een hupostasis van die Logos het tot die gevolgtrekking gelei dat Jesus geen menselike hupostasis gehad het nie. Alle ander mense het $\mathrm{n}$ menslike natuur en dit het hulle in gemeen met Jesus, maar Hy alleen het geen menslike hupostasis nie.

Volgens Johannes Damascenus kan geen natuur sonder 'n hupostasis wees nie. Elke natuur hoef egter nie sy eie hupostasis te hê nie, maar kan dit ook met ander entiteite deel. Dit was die geval met die geïnkarneerde Woord. Die mens Jesus het Sy eie menslike natuur gehad, maar sy hupostasis was die van die goddelike Logos.

Hierdie manier van redenering maak volgens Van Buren van Jesus alleen 'n besoeker en maak hom nie deel van die menslike geslag nie.

Wat wil die leer van die inkarnasie dan sê? Dit wil heenwys na 'n mens, Jesus, wat 'n besondere roeping ontvang het waarop $\mathrm{Hy}$ in sy lewe geantwoord het. Hy was ' $n$ mens in die geskiedenis wat vryheid geleef het en wie se vryheid na Pase aansteeklik geword het. Dit wil sê dat ons betrokke is by die geskiedenis van die mens Jesus van Nasaret, wat so vir ons die vyheid geleef het.

Die vryheid wat Jesus geleef het, en wat nie eintlik beskryf kan word nie, maar waarvan 'n beeld voor ons staan in die 'glimpses' van Jesus wat ons in die evangelies vind, was 'n duidelike aanslag op die wêreld wat Hom gekruisig het. Die kruis was die oorwinning van sy vryheid - Hy wat vry was van homself en selfbehoud, vry vir ander - en die kerugma van die opstanding was 'n bevestiging van die oorwinning van sy vryheid. Na pase gaan hierdie vryheid op ander oor en hulle leef hierdie vryheid, gebrekkig, onvolmaak, altyd weer terug in die ou wêreld, terwyl hulle Jesus as Verlosser erken.

Die historiese Jesus alleen, sonder inagneming van die paasgebeure, kan nie geloof laat ontstaan in die sin van response van die vroeë Christendom nie. Geloof is nie gegrond in die historiese figuur alleen, los van pase nie. Maar ons moet tog in gedagte hou dat die prediking wat in die Nuwe Testament gevind word, heenwys na 
die historiese mens as voorbeeld van mens-wees. Daarom moet die gelowige sy verstaan van en sy antwoord op enige konkrete situasie in die lewe, ook toets soos dit gereflekteer word deur die geskiedenis van Jesus.

Die Christelike geloof het ook te doen met 'n historiese mens wat werklik geleef het, gesterwe het en begrawe is. Maar, en dit mag nie vergeet word nie, tussen ons en die lewe van Jesus, is die Paasgebeure.

Oor die opstanding wil hy die vraag beantwoord of hier van 'n feit sprake is of nie. Wie na byvoorbeeld 1 Korintiërs 15: $37 \mathrm{kyk}$, sal aanvanklik dink dat dit hier om feite gaan, maar gaan dit daarom? 'n Feit moet beskryf kan word. Van voor Pase kan ons sê dat Jesus gekruisig en begrawe is en dat die dissipels teleurgesteld was. Die opstanding kan nie so beskrywe word nie.

Ook die verskynings na die opstanding, kan nie in ons tyd sonder meer as feite gestel word nie. Met ons kennis van wat met selle gebeur na die dood, sal so 'n beskrywing net nie stand hou nie. Die paas-kerugma gaan daarom klaarblyklik nie oor 'n fisiese feit nie.

Wat met pase gebeur het, is dat die dissipels ander mense geword het. Hulle het hulle skielik vasgevang gevoel in die vryheid van Jesus. Dit het ingehou dat hulle so vry geword het dat hulle selfs die dood sonder vrees tegemoet kon gaan. Al wat ons dus kan sê, is dat daar iets gebeur het. Die ou tradisie het hierdie iets wat gebeur het, beskrywe met die woorde 'Hy het verskyn'. Die stelling 'Hy het aan my verskyn', wil nie 'n werklikheid aandui nie, maar dit wil sê dat die dissipel Petrus dit 'on the mirror of his mind' gehad het. Van Buren noem hierdie stelling 'n 'sensecontent' stelling. Dit is anders as ' $n$ 'common-sense' stelling of ' $n$ empiriese stelling aangesien dit nie op dieselfde wyse geverifieer kan wrod nie. Die metode waarop 'n 'sense-content' stelling geverifieer kan word, is om te kyk of die woorde en dade van die persoon wat die stelling maak, dit bevestig. So word byvoorbeeld Petrus se stelling van 'sense-content' wat die man wat hy gesien het identifiseer met Jesus, wat 'n sekere lewe geleef het, geverifieer deur Petrus se daaropvolgende lewe.

Hierdie stelling van Petrus is egter gevolg deur nog ' $n$ ander stelling, naamlik 'Jesus is risen'. Dit is 'n linguistiese 'odd' stelling. Die getuienis dui egter volgens Van Buren, daarop dat die dissipels nie 'n fisiese opstanding van Jesus in gedagte gehad het nie. So was die opgestane liggaam nie soos die aardse nie (1 Kor 15: 35 ev), en alhoewel dit die merke van die kruisiging gedra het (Luk 24:39; Joh 20: 20,27), het die dissipels moeite ondervind om die opgestane Jesus te herken (Matt 28:17; Luk 24:16, 37,41; Joh 20:15; 21:14). Die 'oddity' van die stelling is afkomstig van die feit dat hier twee verskillende taalspele naas mekaar geplaas word.

Daar moet opgelet word dat Jesus 'n eienaam is en dat dit logies verkeerd is om in die stelling 'Jesus is risen' die woordjie 'is' met 'n persoon te verbind wat 
reeds dood is. In hierdie geval vorm 'is' deel van 'n werkwoord wat sy logiese plek in die Joodse eskatologie het. Die woordjie 'opgestaaan' dui op die koninkryk van God en dui op die doel van alle eksistensie.

Die stelling 'Jesus is risen', neem nou 'n historiese mens en sê, 'he was of the realm of the end'. Dit is 'n 'end word' en die bedoeling van 'n 'end word' is om 'n sekere houding van die spreker na vore te bring. So 'n stelling is byvoorbeeld 'Die koninkryk van God is naby'. Op sy eie geneem, kan die stelling nie geverifieer word nie, maar die houding waarmee die stelling meegedeel word, is oop vir verifikasie.

Dit kan byvoorbeeld beteken: lewe vir die hede eerder as om planne vir die oudag te beraam.

Die stelling 'Jesus is risen' beweeg nou in dieselfde rigting en moet derhalwe geverifieer word op grond van die houding van die een wat dit gesê het. Die geldigheid van die stelling kan dus daarin geleë wees dat die een wat dit gesê het, soos Jesus gaan leef het en gaan sterf het. Dit gaan dus daarom dat die dissipels Jesus in 'n nuwe lig gesien het en in Sy vryheid gedeel het. Hulle het gedeel in die vryheid om vir andere te wees. Van Buren (1966) som dit so op:

Jesus of Nazareth was a free man in his own life, who attracted followers and created enemies according to the dynamics of personality and in a manner comparable to the effect of other liberated persons in history upon people about them. He died as a result of the threat that such a free man poses for insecure and bound mens. His disciples were left no less insecure and frightened.

\section{VERANTWOORDING}

Die vraag sou nou wees: Wanneer ons 'n terugblik op die teologiese ontwerp van $P$ van Buren ten behoewe van die gesekulariseerde mens, werp, wat moet ons dan daarvan sê?

Miskien sal die beste antwoord wees om te begin deur te sê dat enige reaksie alleen maar 'n voorlopige reaksie kan wees. Daar sou sekerlik fundamentele kritiek teen Van Buren se hantering van die kerklike belydenis uitgespreek kan word. En sulke kritiek sou selfs nie onvanpas wees nie. Daar kan ten slotte selfs gevra word of hy enigsins die evangelie wat hy wou red, help red het.

Maar laat ons op 'n ander punt begin en 'n kritiese waardering in die verband onder woorde probeer bring.

Die vraag by hom aan orde was: Hoe kan 'n Christen wat 'n gesekulariseerde mens is sy geloof op 'n sekulêre wyse verstaan? 
Van Buren het probeer om die vraag te beantwoord deur te analiseer wat 'n mens bedoel wanneer hy die taal van die geloof gebruik en die vroegste Christelike belydenis dat Jesus die Here is, uitspreek. Hy het gepoog om die taal van die geloof te analiseer deur gebruik te maak van die 'linguistic analysis'. Op die wyse wou hy die bedoeling van stellings nagaan om uit te vind wat dit oorspronklik beteken. In die proses het hy baie sekuriteite bevraagteken en tog probeer vashou daaraan dat sonder Pase daar geen evangelie moontlik sou wees nie. Selfs 'n geskiedenis van Jesus sonder paasfees is geen basis vir die Christelike geloof nie. Wanneer dit gestel word, is die betekenis van die evangelie vir hom in die historiese en etiese en nie in die metafisiese nie.

Sy grootste fout was heelwaarskynlik dat hy binne die konteks van die logiespositivisme die verifikasie beginsel op teologiese uitsprake van toepassing gemaak het. Dit het uiteindelik daartoe moes lei dat daar weinig van die evangelie oorgebly het.

Sy waarde setel egter daarin dat hy raakgesien het dat die verhaal van Jesus soos vertel deur die kerk opnuut geïnterpreteer moet word vir gesekulariseerde mense. Dit sou nie genoeg wees om net te herhaal nie, daar moet in 'n idioom gepraat word wat God opnuut ter sprake kan laat kom sodat daar 'n lewende belydenis binne die kerk kan wees.

'Die teologie weerspieël (immers) die denkstrominge van die tyd. Die 'ewige' waarmee die teologie sigself besig hou, verhinder nie dat die spore wat die teologiese denke in die tyd nalaat, sterk ooreenkomste vertoon met die denke van die tyd nie' (Du Toit 1988: 36).

Van Buren was in die verband ook 'n kind van sy tyd. Vandag worstel ons nog steeds met die sistematiese deurdenking van die heil wat daar in Jesus Christus is (Berkhof 1982:13).

In die verband bly ' $n$ woord van Berkhof (1982:22) waar: Die dogmatiek kan nie sonder die konfessionele dimensie bestaan nie. Dit kan nie sonder die verworteling in 'n lewende kerk met sy tradisie leef nie. Wanneer die dogmatikus homself bo die konfessies stel, stel hy homself buite die realiteit van waaruit en waaroor hy wil reflekteer.

Die verhaal van God se heilshandeling met die mense is voortgedra deur die kerk. Binne die kerk het dit telkens tot lewende geloofsbelydenisse geword. Hierdie verhaal moet so voortgedra word dat dit telkens weer in 'n lewende belydenis na vore sal tree. Hierin moet die dogmatikus dankbaar die dieptepeiling en die daarby behorende beslissinge van sy kerk of konfessie deurdink en tot sprake laat kom. Natuurlik nie as finale gesag nie. Die Skrif staan altyd daarbo en kan ook die dogmatiese deurdenking en die konfessionele tradisie komplementeer kritiseer en 
relativeer.

Dit maak teologiebeoefening so opwindend. Hierin het Van Buren ook 'n poging aangewend en dalk ' $n$ onvoldoende poging. Maar dit het prof FJ van $\mathrm{Zyl}$ ons geleer: of jy staan in die geloof (fides qua creditur) en probeer verstaan wat jy glo (fides quae creditur), of jy staan buite die geloof en verstaan niks van die evangelie nie.

\section{Literatuurverwysings}

BERKHOF, H 1982. Inleiding tot de studie van de Dogmatiek. Kampen: Kok.

BULTMANN, R 1951. Jesus. Tübingen: Mohr.

CULLMANN, O 1943. Die erste Christlichen Glaubens bekentnisse. Zollikon: Evangelische Verlag.

DU TOIT, C 1988. Aspekte van die postmodernistiese idioom in die teologie. Theologia Evangelica, 36-50.

VAN BUREN, P 1966. The secular meaning of the gospel. 3rd ed. London: SCM.

VAN BUREN, P 1967. Theology in the context of culture in Frontline Theology. London: SCM.

VAN BUREN, P 1968. Theological explorations. London: SCM. 